\title{
An association between uric acid levels and renal arteriolopathy in chronic kidney disease: a biopsy-based study
}

\begin{abstract}
Kentaro Kohagura ${ }^{1}$, Masako Kochi ${ }^{1}$, Tsuyoshi Miyagi ${ }^{1}$, Takanori Kinjyo ${ }^{1}$, Yuichi Maehara ${ }^{1}$, Kazufumi Nagahama ${ }^{1}$, Atsushi Sakima ${ }^{1}$, Kunitoshi Iseki ${ }^{2}$ and Yusuke Ohya ${ }^{1}$

Uric acid (UA) can induce renal arteriolopathy in animal models. Whether there is an association between UA and renal arteriolopathy in patients with chronic kidney disease (CKD) is unknown. Here, we examined the cross-sectional association of serum UA levels with renal arteriolar hyalinosis and wall thickening. Arteriolar parameters were assessed by semiquantitative grading (max: grade 3) of arterioles in 167 patients with CKD (mean age, 42.4 years; 86 men and 81 women) who underwent renal biopsy. The mean serum UA level was $6.4 \mathrm{mg} \mathrm{dl}^{-1}$. We observed hyalinosis in 94 patients $(56 \%)$ and wall thickening in 119 patients (71\%). As the UA level tertile increased, the proportion of higher-grade (grade 2 and 3 ) hyalinosis and wall thickening increased (hyalinosis, $\boldsymbol{P}<0.0001$ and wall thickening, $\boldsymbol{P}=\mathbf{0 . 0 0 0 2}$, for trend). Multiple logistic analysis adjusted for age $\geqslant 40$ years, sex, hypertension status, diabetes mellitus status and estimated glomerular filtration rate $<60 \mathrm{ml} \mathrm{min}^{-1}$ per $1.73 \mathrm{~m}^{2}$ showed that hyperuricemia $\left(\mathrm{UA} \geqslant 7 \mathrm{mg} \mathrm{dl}^{-1}\right.$ ) was significantly associated with a higher risk of hyalinosis (adjusted odds ratio: $3.13 ; 95 \%$ confidence interval: $1.23-7.94 ; \boldsymbol{P}=0.02$ ) and higher-grade (equal to or higher than the mean value) wall thickening (adjusted odds ratio: $2.66 ; 95 \%$ confidence interval: $1.11-6.38 ; P=0.03$ ). Hence, these results suggest that hyperuricemia may be related to renal arteriolar damage in patients with CKD.

Hypertension Research (2013) 36, 43-49; doi:10.1038/hr.2012.135; published online 6 September 2012
\end{abstract}

Keywords: chronic kidney disease; renal arteriolopathy; uric acid

\section{INTRODUCTION}

Hyperuricemia, which is often a complication of chronic kidney disease (CKD), is likely to have a pathogenic role in the progression of kidney disease. ${ }^{1,2}$ We previously reported in a community-based survey that hyperuricemia is a significant risk factor for the development of renal insufficiency. ${ }^{3}$ Others have also reported that hyperuricemia is associated with an increased risk of the progression of CKD in various conditions, such as diabetic nephropathy and primary glomerular disease. ${ }^{4,5}$ Furthermore, experimental studies have demonstrated that hyperuricemia can induce an increase in blood pressure and the progression of renal failure. ${ }^{1,6}$

Although the mechanism of the association between hyperuricemia and the progression of CKD has not been clearly elucidated in a clinical setting, the results of animal studies suggest that hyperuricemia might cause the progression of CKD by inducing preglomerular arteriolar damage, characterized by hyalinosis and wall thickening. ${ }^{1,6}$ Preglomerular microvessels have a pivotal role in the regulation of glomerular hemodynamics. Therefore, damage to the preglomerular arterioles could cause glomerular hypertension and ischemia, which are universal risk factors for the progression of renal disease. This idea is supported by a histological analysis conducted by Hill et al. ${ }^{7,8}$ who elegantly showed in renal biopsy specimens that hyalinotic changes of the afferent arteriole might be crucial as a potential marker of disrupted glomerular hemodynamic autoregulation. Moreover, a micropuncture study conducted by Sánchez-Lozada et al. ${ }^{9}$ demonstrated that medial thickening of the arteriole correlated with glomerular capillary pressure in the animal model of hyperuricemia. In addition, they showed that serum uric acid (UA) levels correlated with glomerular capillary pressure. These findings suggested that the association between UA and renal arteriolopathy might have a significant role in the progression of renal disease. However, information regarding an association between UA and changes in the renal arterioles in humans is limited. In this study, we examined these factors in patients with CKD who underwent renal biopsy.

${ }^{1}$ Department of Cardiovascular Medicine, Nephrology and Neurology, University of the Ryukyus School of Medicine, Okinawa, Japan and ${ }^{2}$ Dialysis Unit, University of the Ryukyus School of Medicine, Okinawa, Japan

Correspondence: Dr K Kohagura, Department of Cardiovascular Medicine, Nephrology and Neurology, University of the Ryukyus School of Medicine, 207 Uehara, Nishihara-cho, Okinawa 903-0215, Japan.

E-mail: kohagura@med.u-ryukyu.ac.jp

Received 7 February 2012; revised 1 May 2012; accepted 13 June 2012; published online 6 September 2012 


\section{METHODS}

\section{Settings and participants}

A total of 207 consecutive patients with CKD who underwent renal biopsy at the University of the Ryukyus Hospital during the period from 1 January 2003 to 31 December 2006 were considered for this study. Twenty-seven of these patients were excluded because of treatment with steroids and/or a calcineurin inhibitor, vasculitis, amyloidosis, purpura nephritis, a transplanted kidney or absence of the appropriate arterioles. Thirteen patients used antiuricemic drugs. As the UA level in these patients did not represent the level before starting treatment with the drug, we also removed these 13 patients. The data for the remaining 167 patients ( 86 men and 81 women) were analyzed in this study. The study protocol was approved by the ethics review board of the University of Ryukyus. All patients gave written informed consent to participate in the study.

\section{Histological diagnosis of renal biopsies}

Based on the renal biopsy findings, the following diagnoses were made for the 167 study participants: 86 had immunoglobulin A nephropathy, 17 had membranous nephropathy, 14 had minor glomerular abnormalities, 3 had focal segmental glomerular sclerosis, 2 had membranoproliferative glomerulonephritis, 2 had non-immunoglobulin A mesangial proliferative glomerulonephritis, 1 had endocapillary proliferative glomerulonephritis, 18 had benign nephrosclerosis, 5 had lupus nephritis, 4 had diabetic nephropathy, 2 had obesity-related glomerulopathy, 2 had hereditary glomerulopathy, 1 had thin basement membrane disease, 1 had Fabry disease, 7 had tubulointerstitial nephritis and 2 had glomerular obsolescence.

\section{Semiquantitative assessment of intrarenal preglomerular vessels} We studied the preglomerular arterioles, including the afferent arteriole and small interlobular artery with 2-3 layers of smooth muscle cells. We identified the hyalinotic lesions as pink amorphous lesions by periodic acid-Schiff staining the arteriolar wall. The arteriolar wall thickening included intimal thickening, medial thickening or both. We assessed arteriolar hyalinosis semiquantitatively in each specimen with a modification of the grading system established by Bader and Kubo ${ }^{10,11}$ as follows: grade 0 (G0), no hyalinosis of the vessel wall; grade 1 (G1), hyalinosis of less than a quarter of the circumference; grade 2 (G2), hyalinosis of a quarter to a half of the circumference; and grade 3 (G3), hyalinosis involving more than half of the circumference of the vessel wall. Based on this grading system, we calculated the mean grade of renal arteriolar hyalinosis (arteriolar hyalinosis index) in each patient according to the following formula: arteriolar hyalinosis index $=(n 0 \times 0+n 1 \times 1+n 2 \times 2+n 3 \times 3) / N$. Here, $n 1, n 2$ and $n 3$ indicate the number of arterioles showing hyalinosis scores of G1-G3, and $N$ indicates the total number of arterioles. Similarly, we assessed wall thickening semiquantitatively in each specimen as follows: grade $0(\mathrm{G} 0)$, no thickening grade 1 (G1), mild thickening; grade 2 (G2), moderate thickening without definite narrowing of the lumen; and grade 3 (G3), severe thickening with definite narrowing of the lumen. Based on this grading system, we calculated the mean grade of renal arteriolar wall thickening (arteriolar wall thickening index) in each patient according to the following formula: arteriolar wall thickening index $=(n 0 \times 0+n 1 \times 1+n 2 \times 2+n 3 \times 3) / N$. To minimize the effect of sampling bias, we analyzed arteriolar hyalinosis and wall thickening by (1) presence or absence, (2) maximum grade and (3) mean grade of all arteriolar hyalinosis (arteriolar hyalinosis index) and all arteriolar wall thickening (arteriolar wall thickening index). Representative microphotographs of each grade of arteriolar hyalinosis and wall thickening are illustrated in Figure 1. All histological analyses were performed by one physician (KK) who was blinded to the patient information.

\section{Association between UA and renal arteriolopathy}

Our epidemiologic studies ${ }^{2,3}$ suggested that there might be a sex difference in the association between UA and renal arteriolopathy. Therefore, we planned a subgroup analysis by sex. We examined the proportion of the maximum grade of renal arteriolar hyalinosis and wall thickening according to the UA tertile according to sex. As the profile of hyalinosis and wall thickening according to UA tertile suggested that there might be a threshold level of UA above which the risk of hyalinosis increased, we analyzed the presence of hyperuricemia, defined as $\geqslant 5, \geqslant 6$ and $\geqslant 7 \mathrm{mg} \mathrm{dl}^{-1} \mathrm{UA}$, according to the presence of renal arteriolar hyalinosis or wall thickening. We also analyzed the determinants of the presence of renal arteriolar hyalinosis and higher-grade renal arteriolar wall thickening, the latter of which is defined as equal to or more than the mean value of the wall thickening index $(\geqslant 0.4$ in all and men, and $\geqslant 0.3$ in women), by logistic analysis. The following variables were included in this analysis: $\geqslant 40$ years age, $\geqslant 25 \mathrm{~kg} \mathrm{~m}^{-2}$ body mass index, hypertensive status,

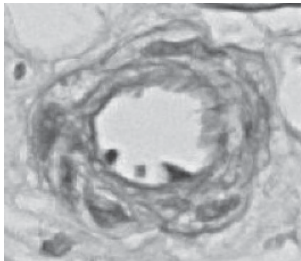

grade 0

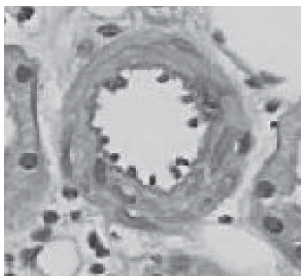

grade 0

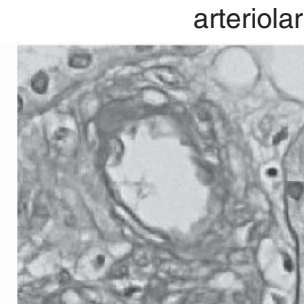

grade 1

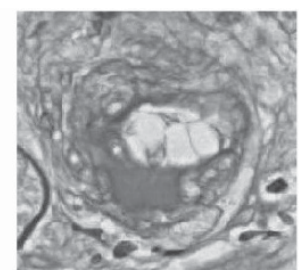

grade 2

arteriolar wall thickening

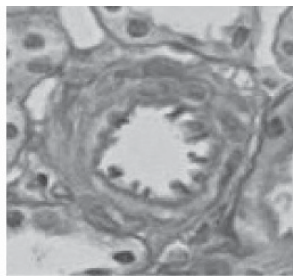

grade 1

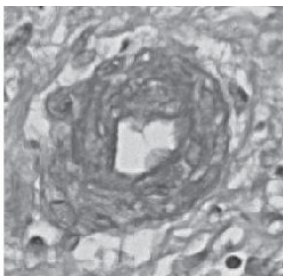

grade 2

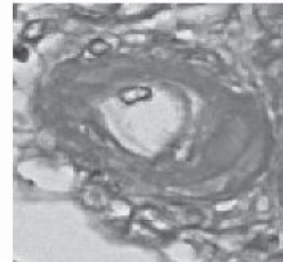

grade 3

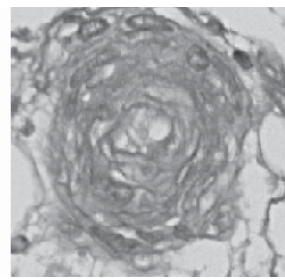

grade 3

Figure 1 Representative microphotographs of arteriolar hyalinosis (grades 0-3) and arteriolar wall thickening (grades 0-3). PAS stain ( $\times 400$ ). Arteriolar hyalinosis was semiquantitatively assessed as follows: grade 0 (GO), no hyalinosis of the vessel wall; grade 1 (G1), hyalinosis of less than one-quarter of the circumference; grade 2 (G2), hyalinosis of one-quarter to one-half of the circumference; and grade 3 (G3), hyalinosis involving more than one-half of the circumference of the vessel wall. Similarly, arteriolar wall thickening was semiquantitatively assessed as follows: grade 0 (GO), no thickening; grade 1 (G1), mild thickening; grade 2 (G2), moderate thickening without definite narrowing of the lumen; and grade 3 (G3), severe thickening with definite narrowing of the lumen. A full color version of this figure is available at the Hypertension Research journal online. 
diabetes mellitus status (or glucose intolerance in women because none of the women with hyalinosis had diabetes mellitus), dyslipidemic status, smoking status, $<60 \mathrm{ml} \mathrm{min}^{-1}$ per $1.73 \mathrm{~m}^{2}$ estimated glomerular filtration rate (eGFR) and hyperuricemia defined as $\geqslant 5, \geqslant 6$ and $\geqslant 7 \mathrm{mg} \mathrm{dl}^{-1} \mathrm{UA}$. We selected these independent variables because there were significant differences in these variables, except for smoking status, between the patients with and without hyalinosis. We also selected smoking status as an independent variable because the previous study suggested that smoking might be associated with arteriolopathy. ${ }^{12}$ In the logistic analysis, body mass index was calculated as weight in kilograms divided by height in meters squared. Diabetes mellitus status and glucose intolerance were determined by a $75-\mathrm{g}$ oral glucose tolerance test or by fasting and measurement of postprandial glucose concentrations in addition to a medical history of diabetes. Dyslipidemia was defined as hyper-low-density lipoprotein cholesterolemia, hypertriglyceridemia, hypo-highdensity lipoprotein cholesterolemia and/or taking medication for dyslipidemia. Smokers were defined as current or exsmokers. GFR was estimated with a new equation for Japanese individuals: eGFR $\left(\mathrm{ml} \mathrm{min}^{-1}\right.$ per $1.73 \mathrm{~m}^{2}=194 \times$ serum creatinine ${ }^{1.094} \times$ age $^{0.287}(\times 0.739$ if female $) .{ }^{13}$ We measured the urine protein in the first-spot morning urine.

\section{Statistical analysis}

The unpaired $t$-test and $\chi^{2}$-test were used to analyze the differences in discrete variables between groups. Univariate correlations were performed using Spearman's correlation coefficient. The $\chi^{2}$-test and Cochran-Armitage trend test were used to analyze the trend for increases in the proportion of higher-grade (maximum-G2 and 3) hyalinosis or wall thickening according to the UA tertiles. Multivariate logistic regression analysis was used to identify the factors associated with arteriolar hyalinosis and wall thickening. The data are expressed as the means (s.d.). The statistical analysis was conducted with Stat View 5.0 and JMP 9 (SAS Institute, Cary, NC, USA). $P$-values $<0.05$ were considered significant.

\section{RESULTS}

The characteristics of the study participants are summarized according to sex in Table 1. The number (\%) of patients in each CKD stage was as follows: stage 1, 63 (37.7); stage 2, 53 (31.7); stage 3, 42 (25.2); stage 4, 6 (3.6); and stage 5, 3 (1.8). Men had similar age and body mass index to thewomen. The prevalence of hypertension in men was similar to women, but the rates of glucose intolerance, dyslipidemia, cigarette smoking and current alcohol drinking were significantly higher in men than those in women. Men also had significantly higher UA levels than women. However, men had similar prevalence of hyperuricemia to the women, which was defined as a UA level $\geqslant 7 \mathrm{mg} \mathrm{dl}^{-1}$ in men and $\geqslant 6 \mathrm{mg} \mathrm{dl}^{-1}$ in women. The proportion treated with diuretics was similar for both sexes, as was renal function. The mean number of arterioles was $7.8 \pm 4.8$ vessels in each patient.

The parameters of renal arteriolar hyalinosis and wall thickening were comparable between the sexes, except for the maximum grade of renal arteriolar hyalinosis.

Relationship between serum UA and index of renal arteriolopathy We examined the relationship between serum UA levels and the index of arteriolopathy (Figure 2). We found a weak but significant

Table 1 Clinical characteristics by sex

\begin{tabular}{|c|c|c|c|c|}
\hline & $\begin{array}{c}A / l \\
\mathrm{~N}=167\end{array}$ & $\begin{array}{c}\text { Men } \\
\mathrm{N}=86\end{array}$ & $\begin{array}{l}\text { Women } \\
\mathrm{N}=81\end{array}$ & P-value \\
\hline Age (years) & $42.4 \pm 18.5$ & $41.8 \pm 18.0$ & $43.0 \pm 19.0$ & NS \\
\hline BMI $\left(\mathrm{kg} \mathrm{m}^{-2}\right)$ & $24.4 \pm 4.8$ & $24.9 \pm 4.4$ & $23.9 \pm 5.0$ & NS \\
\hline Diabetes mellitus & $20(12)$ & $13(15)$ & $7(9)$ & NS \\
\hline Hypertension & $75(45)$ & $43(50)$ & $32(40)$ & NS \\
\hline Dyslipidemia & $101(60)$ & $59(69)$ & $42(52)$ & 0.03 \\
\hline Hyperuricemia & $70(42)$ & $36(42)$ & $34(42)$ & NS \\
\hline Smoking & $63(38)$ & $56(65)$ & $7(9)$ & $<0.0001$ \\
\hline Alcohol & $41(25)$ & $33(38)$ & $8(10)$ & $<0.0001$ \\
\hline Systolic blood pressure (mm Hg) & $129.0 \pm 21.2$ & $131.1 \pm 18.5$ & $126.8 \pm 23.6$ & NS \\
\hline Diastolic blood pressure $(\mathrm{mm} \mathrm{Hg})$ & $75.7 \pm 11.9$ & $76.9 \pm 12.5$ & $74.5 \pm 11.5$ & NS \\
\hline Proteinuria (per g creatinine) & $2.4 \pm 3.7$ & $2.9 \pm 4.5$ & $1.9 \pm 2.6$ & NS \\
\hline Serum creatinine $\left(\mathrm{mg} \mathrm{dl}^{-1}\right)$ & $1.0 \pm 0.7$ & $1.2 \pm 0.9$ & $0.7 \pm 0.3$ & $<0.0001$ \\
\hline eGFR $\left(\mathrm{ml} \mathrm{min}^{-1}\right.$ per $\left.1.73 \mathrm{~m}^{2}\right)$ & $81.7 \pm 35.8$ & $78.2 \pm 35.9$ & $85.4 \pm 35.6$ & NS \\
\hline Serum uric acid (mg dl-1) & $6.4 \pm 1.6$ & $6.9 \pm 1.6$ & $5.8 \pm 1.5$ & $<0.0001$ \\
\hline LDL cholesterol (mg dl-1) & $130.2 \pm 66.3$ & $131.2 \pm 78.7$ & $129.1 \pm 50.6$ & NS \\
\hline Triglyceride (mg dl $\left.{ }^{-1}\right)$ & $183.3 \pm 140.9$ & $218.1 \pm 170.0$ & $146.2 \pm 88.2$ & 0.0008 \\
\hline HDL cholesterol (mg dl-1) & $57.2 \pm 19.8$ & $50.0 \pm 16.1$ & $64.9 \pm 20.5$ & $<0.0001$ \\
\hline Renal arteriolar hyalinosis, number (\%) & $94(56)$ & $54(63)$ & $40(49)$ & NS \\
\hline Renal arteriolar hyalinosis, index & $0.5 \pm 0.6$ & $0.6 \pm 0.6$ & $0.4 \pm 0.6$ & NS \\
\hline Renal arteriolar hyalinosis, max. grade & $1.1 \pm 1.1$ & $1.3 \pm 1.2$ & $0.8 \pm 1.0$ & 0.01 \\
\hline Renal arteriolar wall thickening, number (\%) & $119(71)$ & $64(54)$ & $55(68)$ & NS \\
\hline Renal arteriolar wall thickening, index & $0.4 \pm 0.4$ & $0.4 \pm 0.5$ & $0.3 \pm 0.4$ & NS \\
\hline Renal arteriolar wall thickening, max. grade & $1.0 \pm 0.8$ & $1.1 \pm 0.9$ & $0.9 \pm 0.8$ & NS \\
\hline Diuretics & $10(6)$ & $5(6)$ & $5(6)$ & NS \\
\hline Angiotensin II receptor antagonist & $38(23)$ & $20(23)$ & $18(22)$ & NS \\
\hline Angiotensin-converting enzyme inhibitor & $13(8)$ & $9(10)$ & $4(5)$ & NS \\
\hline Calcium channel blocker & 32 (19) & $17(20)$ & 15 (19) & NS \\
\hline Other antihypertensive drugs & $8(5)$ & $5(6)$ & $3(4)$ & NS \\
\hline Statins & $21(13)$ & $11(13)$ & $10(12)$ & NS \\
\hline
\end{tabular}

Abbreviations: BMI, body mass index; eGFR, estimated glomerular filtration rate; HDL, high-density lipoprotein; LDL, low-density lipoprotein; max., maximum; NS, not significant.

Data are expressed as mean \pm s.d. or number $(\%)$, Hyperuricemia was defined as uric acid $(U A) \geqslant 7 \mathrm{mgdl}^{-1}$ among men and UA $\geqslant 6 \mathrm{mgdl}-1$ among women. Conversion factor for unit: serum creatinine in $\mathrm{mg} \mathrm{dl}^{-1}$ to $\mathrm{moll}^{-1}, \times 88.4$ 
correlation between UA levels and the renal arteriolar hyalinosis index $(r=0.28, P=0.0002)$ and the wall thickening index $(r=0.31$, $P<0.0001)$.

Proportion of the maximum grade of renal arteriolar hyalinosis The prevalence of renal arteriolar hyalinosis was significantly higher in the second and third UA tertiles than in the first tertile for all patients (Figure 3a). The proportion of higher-grade (grade 2 and 3 ) arteriolar hyalinosis showed a significant association with the UA
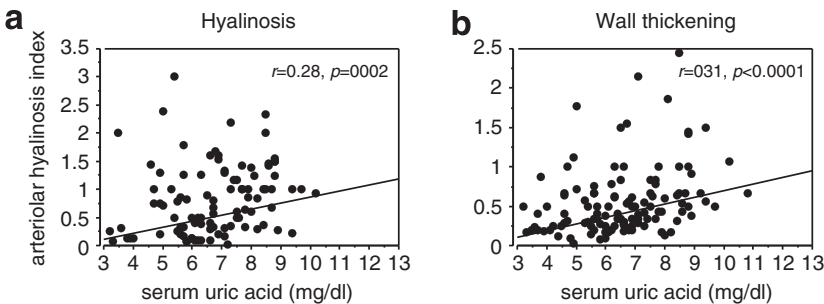

Figure 2 Relationship between serum UA levels and renal arteriolar hyalinosis index (a) and renal arteriolar wall thickening index (b). There was a weak but significant correlation between UA levels and the renal arteriolar hyalinosis index $(r=0.28, P=0.0002)$ and between UA levels and the wall thickening index $(r=0.31, P<0.0001)$.
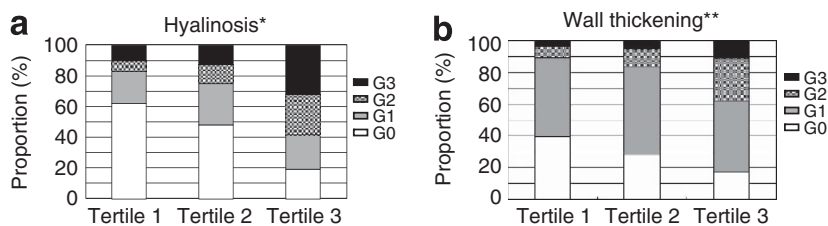

Figure 3 Proportion of patients with maximum-grade renal arteriolar hyalinosis (a) and arteriolar wall thickening (b) according to the tertile of UA level. Cutoffs for the tertiles: 5.7 and $7.0 \mathrm{mgdl}^{-1}$ for all patients. As the UA level tertile increased, the proportion of higher-grade (G2 and G3) hyalinosis and wall thickening increased ( ${ }^{*} P<0.0001$ for hyalinosis and ${ }^{* *} P=0.0002$ for wall thickening, for the intertertile trend). tertile (the first tertile $17.3 \%$, the second tertile $25.0 \%$ and the third tertile 58.5\%, respectively, $P<0.0001$ for the trend) for all patients. Similar trends were also observed separately in men and women, as follows: the first tertile $20.0 \%$, the second tertile $34.5 \%$ and the third tertile $70.4 \%$, respectively, $P<0.0001$ for the trend in men; the first tertile $19.2 \%$, the second tirtile $11.5 \%$ and the third tertile $41.4 \%$, respectively, $P=0.03$ for the trend in women.

\section{Proportion of the maximum grade of renal arteriolar wall thickening}

The prevalence of renal arteriolar wall thickening was significantly higher in the second and third UA tertiles than in the first tertile for all patients (Figure 3b). The proportion of higher-grade (grade 2 and 3) arteriolar wall thickening showed a significant association with the UA tertile (the first tertile $10.3 \%$, the second tertile $16.1 \%$ and the third tertile $37.7 \%$, respectively, $P=0.0002$ for the trend) among all patients. Similar trends were also observed separately in men and women as follows: the first tertile $10.0 \%$, the second tertile $24.1 \%$ and the third tertile $44.4 \%$, respectively, $P=0.002$ for the trend in men; the first tertile $3.9 \%$, the second tertile $11.5 \%$ and the third tertile $31.0 \%$, respectively, $P=0.003$ for the trend in women.

The proportion of higher-grade hyalinosis and wall thickening were clearly higher in tertile 3 than in the other tertiles. These findings suggested that there might be a cutoff value of UA above which the risk of the presence of renal arteriolopathy increases. Therefore, we examined the association of UA with renal arteriolopathy using different definitions of hyperuricemia as follows: $\geqslant 5, \geqslant 6$ or $\geqslant 7 \mathrm{mg} \mathrm{dl}^{-1} \mathrm{UA}$ according to sex.

Clinical characteristics according to the presence of renal arteriolar hyalinosis or wall thickening

In addition to hypertension and diabetes mellitus, hyperuricemia (which was defined as $\geqslant 5, \geqslant 6$ or $\geqslant 7 \mathrm{mg} \mathrm{dl}^{-1} \mathrm{UA}$ ) was more prevalent in the patients with renal arteriolar hyalinosis (Table 2). Similarly, hyperuricemia, which was defined as $\geqslant 6$ or $\geqslant 7 \mathrm{mg} \mathrm{dl}^{-1}$, was more prevalent in the patients with arteriolar wall thickening. The presence $(\%)$ of hyperuricemia in patients with or without arteriolar wall thickening was as follows: UA $\geqslant 6 \mathrm{mg} \mathrm{dl}^{-1}, 79$ (66) and

Table 2 Clinical characteristics by the presence of renal arteriolar hyalinosis

\begin{tabular}{|c|c|c|c|c|c|c|c|c|c|}
\hline & \multicolumn{3}{|c|}{$A / /(\mathrm{N}=167)$} & \multicolumn{3}{|c|}{ Men $(\mathrm{N}=86)$} & \multicolumn{3}{|c|}{ Women $(\mathrm{N}=81)$} \\
\hline & $\begin{array}{c}\text { Hyalinosis (-) } \\
\mathrm{N}=73\end{array}$ & $\begin{array}{c}\text { Hyalinosis (+) } \\
\qquad \mathrm{N}=94\end{array}$ & P-value & $\begin{array}{c}\text { Hyalinosis (-) } \\
\mathrm{N}=32\end{array}$ & $\begin{array}{c}\text { Hyalinosis (+) } \\
\qquad N=54\end{array}$ & P-value & $\begin{array}{c}\text { Hyalinosis (-) } \\
\qquad \mathrm{N}=41\end{array}$ & $\begin{array}{l}\text { Hyalinosis (+) } \\
\qquad \mathrm{N}=40\end{array}$ & P-value \\
\hline Age (years) & $32.8 \pm 17.1$ & $49.8 \pm 15.9$ & $<0.0001$ & $31.4 \pm 18.0$ & $47.9 \pm 15.1$ & $<0.0001$ & $33.9 \pm 16.5$ & $52.5 \pm 16.0$ & $<0.0001$ \\
\hline Male sex & $32(44)$ & $54(57)$ & NS & & & & & & \\
\hline $\mathrm{BMI}\left(\mathrm{kg} \mathrm{m}^{-2}\right)$ & $23.6 \pm 5.2$ & $25.1 \pm 4.2$ & 0.04 & $23.9 \pm 4.6$ & $25.5 \pm 4.3$ & NS & $23.3 \pm 5.5$ & $24.5 \pm 4.2$ & NS \\
\hline Hypertension & $17(23)$ & $58(62)$ & $<0.0001$ & $9(23)$ & $34(63)$ & 0.002 & $8(20)$ & $24(60)$ & 0.0002 \\
\hline Diabetes mellitus & $1(1)$ & $19(20)$ & 0.0002 & $1(3)$ & $12(22)$ & 0.02 & $0(0)$ & $7(18)$ & 0.005 \\
\hline Dyslipidemia & $37(51)$ & $64(68)$ & 0.02 & $20(63)$ & $39(72)$ & NS & $17(41)$ & $25(63)$ & NS \\
\hline Smoking & $25(34)$ & $38(40)$ & NS & $21(66)$ & $35(65)$ & NS & $4(10)$ & $3(8)$ & NS \\
\hline eGFR $\left(\mathrm{ml} \mathrm{min}{ }^{-1}\right.$ per $\left.1.73 \mathrm{~m}^{2}\right)$ & $97.6 \pm 36.8$ & $69.3 \pm 29.8$ & $<0.0001$ & $93.4 \pm 39.0$ & $69.2 \pm 30.9$ & 0.002 & $100.9 \pm 35.2$ & $69.5 \pm 28.7$ & $<0.0001$ \\
\hline \multicolumn{10}{|l|}{ Hyperuricemia, defined as } \\
\hline$\geqslant 5 \mathrm{mgdl}^{-1}$ & $50(68)$ & $82(87)$ & 0.03 & $28(88)$ & $49(91)$ & NS & $22(54)$ & $33(83)$ & 0.005 \\
\hline$\geqslant 6 \mathrm{mg} \mathrm{dl}^{-1}$ & $34(47)$ & $66(70)$ & 0.002 & $23(72)$ & $43(80)$ & NS & $11(27)$ & $23(57)$ & 0.005 \\
\hline$\geqslant 7 \mathrm{mg} \mathrm{dl}^{-1}$ & $10(14)$ & $43(46)$ & $<0.0001$ & $6(19)$ & $29(54)$ & 0.001 & $4(10)$ & $14(35)$ & 0.006 \\
\hline
\end{tabular}

Abbreviations: BMI, body mass index; eGFR, estimated glomerular filtration rate; NS, not significant.

Data are expressed as mean \pm s.d. or number $(\%)$. 
Table 3 ORs of risk factors for the presence of renal arteriolar hyalinosis by sex

\begin{tabular}{|c|c|c|c|c|c|c|c|c|c|}
\hline \multirow[b]{2}{*}{ Risk factor } & \multicolumn{3}{|c|}{ All } & \multicolumn{3}{|c|}{ Men } & \multicolumn{3}{|c|}{ Women } \\
\hline & $\begin{array}{l}\text { Unadjusted } \\
\text { OR (95\% CI) }\end{array}$ & $\begin{array}{l}\text { Age adjusted } \\
\text { OR }(95 \% \mathrm{Cl})\end{array}$ & $\begin{array}{l}\text { Multivariate } \\
\text { OR }(95 \% \mathrm{Cl})\end{array}$ & $\begin{array}{l}\text { Unadjusted } \\
\text { OR }(95 \% \mathrm{Cl})\end{array}$ & $\begin{array}{l}\text { Age adjusted } \\
\text { OR (95\% Cl) }\end{array}$ & $\begin{array}{l}\text { Multivariate } \\
\text { OR }(95 \% \mathrm{Cl})\end{array}$ & $\begin{array}{c}\text { Unadjusted } \\
\text { OR (95\% Cl) }\end{array}$ & $\begin{array}{l}\text { Age adjusted } \\
\text { OR (95\% Cl) }\end{array}$ & $\begin{array}{l}\text { Multivariate } \\
\text { OR (95\% Cl) }\end{array}$ \\
\hline $\begin{array}{l}\text { Age } \geqslant 40 \text { years } \\
(\text { vs. }<40)\end{array}$ & $\begin{array}{c}4.19^{*} \\
(2.17-7.95)\end{array}$ & & $\begin{array}{c}1.87 \\
(0.83-4.17)\end{array}$ & $\begin{array}{c}4.71^{*} \\
(1.82-12.20)\end{array}$ & & $\begin{array}{c}3.57^{* *} \\
(1.21-10.51)\end{array}$ & $\begin{array}{c}4.04^{*} \\
(1.60-10.23)\end{array}$ & & $\begin{array}{c}1.29 \\
(0.39-4.27)\end{array}$ \\
\hline $\begin{array}{l}\mathrm{BMI} \geqslant 25 \mathrm{~kg} \mathrm{~m}^{-2} \\
(\text { vs. }<25)\end{array}$ & $\begin{array}{c}2.00 * * \\
(1.04-3.83)\end{array}$ & $\begin{array}{c}1.48 \\
(0.74-2.97)\end{array}$ & & $\begin{array}{c}2.57^{* *} \\
(1.04-6.38)\end{array}$ & $\begin{array}{c}1.94 \\
(0.74-5.11)\end{array}$ & & $\begin{array}{c}1.18 \\
(0.44-3.18)\end{array}$ & $\begin{array}{c}0.73 \\
(0.24-2.20)\end{array}$ & \\
\hline $\begin{array}{l}\text { Hypertension } \\
\text { (yes/no) }\end{array}$ & $\begin{array}{c}5.31^{*} \\
(2.68-10.52)\end{array}$ & $\begin{array}{c}3.62 * * \\
(1.71-7.65)\end{array}$ & $\begin{array}{c}2.05 \\
(0.89-4.74)\end{array}$ & $\begin{array}{c}4.34^{*} \\
(1.68-11.21)\end{array}$ & $\begin{array}{c}2.87^{* *} \\
(1.03-8.00)\end{array}$ & $\begin{array}{c}1.88 \\
(0.62-5.74)\end{array}$ & $\begin{array}{c}6.19^{* *} \\
(2.28-16.79)\end{array}$ & $\begin{array}{c}4.32^{* *} \\
(1.38-13.53)\end{array}$ & $\begin{array}{c}4.66^{* *} \\
(1.31-16.66)\end{array}$ \\
\hline $\begin{array}{l}\text { Diabetes mellitus } \\
\text { (yes/no) }\end{array}$ & $\begin{array}{c}18.24^{*} \\
(2.38-139.84)\end{array}$ & $\begin{array}{c}12.73^{* *} \\
(1.62-99.98)\end{array}$ & $\begin{array}{c}10.80 * * \\
(1.31-88.87)\end{array}$ & $\begin{array}{c}8.56^{* *} \\
(1.09-71.78)\end{array}$ & $\begin{array}{c}6.56 \\
(0.77-55.80)\end{array}$ & & $\begin{array}{c}7.40 * * \\
(1.52-35.97)\end{array}$ & $\begin{array}{c}4.21 \\
(0.79-22.36)\end{array}$ & \\
\hline Smoking (yes/no) & $\begin{array}{c}1.30 \\
(0.69-2.46)\end{array}$ & $\begin{array}{c}1.00 \\
(0.56-2.17)\end{array}$ & & $\begin{array}{c}0.97 \\
(0.38-2.42)\end{array}$ & $\begin{array}{c}0.71 \\
(0.26-1.95)\end{array}$ & & $\begin{array}{c}0.75 \\
(0.16-3.58)\end{array}$ & $\begin{array}{c}0.42 \\
(0.08-2.21)\end{array}$ & \\
\hline $\begin{array}{l}\text { eGFR }<60 \mathrm{ml} \mathrm{min}^{-1} \\
\text { per } 1.73 \mathrm{~m}^{2} \\
(\text { vs. } \geqslant 60)\end{array}$ & $\begin{array}{c}4.88^{*} \\
(2.23-10.64)\end{array}$ & $\begin{array}{c}3.32^{*} \\
(1.46-7.58)\end{array}$ & $\begin{array}{c}1.47 \\
(0.55-3.92)\end{array}$ & $\begin{array}{c}3.47^{* *} \\
(1.23-9.80)\end{array}$ & $\begin{array}{c}2.21 \\
(0.72-6.76)\end{array}$ & & $\begin{array}{c}6.85^{*} \\
(2.04-22.73)\end{array}$ & $\begin{array}{c}4.72^{* *} \\
(1.33-16.67)\end{array}$ & $\begin{array}{c}2.76 \\
(0.71-10.75)\end{array}$ \\
\hline $\begin{array}{l}\text { Hyperuricemiab } \\
\text { (yes/no) }\end{array}$ & $\begin{array}{c}5.32^{*} \\
(2.43-11.6)\end{array}$ & $\begin{array}{c}4.18^{* *} \\
(1.86-9.43)\end{array}$ & $\begin{array}{c}3.13^{* *} \\
(1.23-7.94)\end{array}$ & $\begin{array}{c}5.03^{*} \\
(1.78-14.08)\end{array}$ & $\begin{array}{c}4.81^{*} \\
(1.61-14.29)\end{array}$ & $\begin{array}{c}3.95^{* *} \\
(1.27-12.35)\end{array}$ & $\begin{array}{c}4.07^{* *} \\
(1.47-11.36)\end{array}$ & $\begin{array}{c}3.48^{* *} \\
(1.20-10.10)\end{array}$ & $\begin{array}{c}3.68^{* *} \\
(1.11-12.20)\end{array}$ \\
\hline
\end{tabular}

Abbreviations: $\mathrm{BMI}$, body mass index; $\mathrm{Cl}$, confidence interval; eGFR, estimated glomerular filtration rate; OR, odds ratio.

Age, sex and all significant risk factors in the age-adjusted analysis were included in the multivariate model. Odds ratios were calculated for increments of risk for the presence of renal arteriolar hyalinosis.

${ }^{*} P<0.005,{ }^{*} P<0.05$

aGlucose intolerance was used in women instead of diabetes mellitus, as there was no patients with diabetes mellitus in the women with hyalinosis.

bWe used the hyperuricemia defined as $\geqslant 7 \mathrm{mgdl}^{-1}$ for all and men, and $\geqslant 5 \mathrm{mgdl}^{-1}$ for women as independent variable. These values were selected as the best discriminators in unadjusted model (the data of other definition were not shown).

21 (44), respectively, $(P=0.007) ; \mathrm{UA} \geqslant 7 \mathrm{mg} \mathrm{dl}^{-1}, 44(37)$ and 9 (19), respectively, $(P=0.02)$.

\section{Logistic analysis}

Determinants of the presence of arteriolar hyalinosis. We used hyperuricemia defined as $\geqslant 7 \mathrm{mg} \mathrm{dl}^{-1}$ for all patients and for men, and $\geqslant 5 \mathrm{mg} \mathrm{dl}^{-1}$ for women as an independent variable (Table 3 ). These values were selected as the best discriminators in the unadjusted model (the data using the other definitions are not shown). In addition to hypertension and diabetes mellitus, hyperuricemia was significantly associated with the presence of renal arteriolar hyalinosis among all patients in the age-adjusted model. Moreover, the association between hyperuricemia and arteriolar hyalinosis remained significant even in the multivariate model, which included an age $\geqslant 40$ years, sex and other significant variables, such as an eGFR $<60 \mathrm{ml} \mathrm{min}^{-1}$ per $1.73 \mathrm{~m}^{2}$, in the age-adjusted model. Additional adjustment with angiotensin receptor blockers and diuretics, which can modulate the serum UA level, had no significant effect on this association. Similarly, hyperuricemia was significantly associated with the presence of hyalinosis in the multivariate model separately in men and women.

Determinants of the presence of higher-grade arteriolar wall thickening. We used hyperuricemia defined as $\geqslant 7 \mathrm{mg} \mathrm{dl}^{-1}$ for all patients and for men, and $\geqslant 6 \mathrm{mg} \mathrm{dl}^{-1}$ for women as an independent variable
(Table 4). This value was selected as the best discriminator in the unadjusted model (the data using the other definitions are not shown). Regarding the determinants of the presence of wall thickening, hyperuricemia was associated with a higher grade of arteriolar wall thickening, defined as equal to or higher than the mean value of the wall thickening index $(\geqslant 0.4$ in all and men, and $\geqslant 0.3$ in women) in the multivariate model, which included an age $\geqslant 40$ years, sex and other significant variables, such as an eGFR $<60 \mathrm{ml} \mathrm{min}^{-1}$ per $1.73 \mathrm{~m}^{2}$, in the age-adjusted model. Similarly, hyperuricemia was significantly associated with a higher grade of wall thickening in the age $(\geqslant 40$ years)-adjusted models separately in men and women.

\section{DISCUSSION}

An association between renal arteriolosclerosis and classical risk factors for cardiovascular disease has previously been demonstrated in both the general population and in patients with CKD. ${ }^{10,12}$ Wu et al. ${ }^{14}$ reported that increased UA levels were associated with intrarenal arterial-arteriolar lesions in patients with immunoglobulin A nephropathy. Consistent with their results, an association between UA levels and the parameters of renal arteriolopathy, such as hyalinosis and wall thickening, was demonstrated in patients with CKD in the present study; increased UA levels were significantly associated with renal arteriolar hyalinosis and wall thickening. Moreover, these associations between higher levels of UA and the parameter 
Table 4 ORs of risk factors for the presence of higher-grade arteriolar wall thickening (equal to or higher than the mean value)

\begin{tabular}{|c|c|c|c|c|c|c|c|c|c|}
\hline \multirow[b]{2}{*}{ Risk factor } & \multicolumn{3}{|c|}{ All } & \multicolumn{3}{|c|}{ Men } & \multicolumn{3}{|c|}{ Women } \\
\hline & $\begin{array}{l}\text { Unadjusted } \\
\text { OR }(95 \% \text { CI) }\end{array}$ & $\begin{array}{l}\text { Age adjusted } \\
\text { OR }(95 \% \mathrm{Cl})\end{array}$ & $\begin{array}{l}\text { Multivariate } \\
\text { OR }(95 \% \text { CI) }\end{array}$ & $\begin{array}{l}\text { Unadjusted } \\
\text { OR }(95 \% \text { CI) }\end{array}$ & $\begin{array}{l}\text { Age adjusted } \\
\text { OR }(95 \% \mathrm{CI})\end{array}$ & Multivariate & $\begin{array}{l}\text { Unadjusted } \\
\text { OR }(95 \% \mathrm{CI})\end{array}$ & $\begin{array}{l}\text { Age adjusted } \\
\text { OR }(95 \% \mathrm{Cl})\end{array}$ & $\begin{array}{l}\text { Multivariate } \\
\text { OR }(95 \% \mathrm{Cl})\end{array}$ \\
\hline Age $\geqslant 40$ years $(v s .<40)$ & $\begin{array}{c}4.48^{*} \\
(2.27-8.85)\end{array}$ & & $\begin{array}{c}1.83 \\
(0.79-4.22)\end{array}$ & $\begin{array}{c}4.55^{*} \\
(1.78-13.33)\end{array}$ & & $\begin{array}{c}1.81 \\
(0.45-7.30)\end{array}$ & $\begin{array}{c}4.72 * \\
(1.82-12.20)\end{array}$ & & $\begin{array}{c}3.41^{* *} \\
(1.24-9.43)\end{array}$ \\
\hline Male sex & $\begin{array}{c}0.97 \\
(0.52-1.81)\end{array}$ & $\begin{array}{c}0.99 \\
(0.51-1.92)\end{array}$ & $\begin{array}{c}0.56 \\
(0.26-1.25)\end{array}$ & & & & & & \\
\hline $\mathrm{BMI} \geqslant 25 \mathrm{~kg} \mathrm{~m}^{-2}($ vs. $<25)$ & $\begin{array}{c}2.44^{* *} \\
(1.28-4.65)\end{array}$ & $\begin{array}{c}1.86 \\
(0.93-3.69)\end{array}$ & & $\begin{array}{c}1.76 \\
(0.77-4.35)\end{array}$ & $\begin{array}{c}1.27 \\
(0.47-3.38)\end{array}$ & & $\begin{array}{c}5.95^{* *} \\
(1.91-18.52)\end{array}$ & $\begin{array}{c}4.52^{* *} \\
(1.38-14.93)\end{array}$ & $\begin{array}{c}4.29 * * \\
(1.26-14.49)\end{array}$ \\
\hline Hypertension (yes/no) & $\begin{array}{c}4.74^{*} \\
(2.42-9.26)\end{array}$ & $\begin{array}{c}3.09^{*} \\
(1.48-6.45)\end{array}$ & $\begin{array}{c}1.67 \\
(0.71-3.92)\end{array}$ & $\begin{array}{c}6.90^{*} \\
(2.41-19.61)\end{array}$ & $\begin{array}{c}4.85^{* *} \\
(1.60-14.71)\end{array}$ & $\begin{array}{c}1.43 \\
(0.33-6.17)\end{array}$ & $\begin{array}{c}3.13^{* *} \\
(1.24-7.94)\end{array}$ & $\begin{array}{c}1.56 \\
(0.52-4.74)\end{array}$ & \\
\hline Diabetes mellitus (yes/no) & $\begin{array}{c}7.94^{*} \\
(2.51-25.00)\end{array}$ & $\begin{array}{c}5.56^{* *} \\
(1.70-18.80)\end{array}$ & $\begin{array}{c}5.59^{* *} \\
(1.55-20.00)\end{array}$ & $\begin{array}{c}9.26^{*} \\
(2.31-37.04)\end{array}$ & $\begin{array}{c}7.52^{* *} \\
(1.76-32.26)\end{array}$ & $\begin{array}{c}9.90^{* *} \\
(1.61-58.82)\end{array}$ & $\begin{array}{c}8.33^{* *} \\
(0.95-71.43)\end{array}$ & $\begin{array}{c}4.29 \\
(0.47-40.00)\end{array}$ & \\
\hline Dyslipidemia (yes/no) & $\begin{array}{c}2.88^{*} \\
(1.45-5.75)\end{array}$ & $\begin{array}{c}1.75 \\
(0.82-3.73)\end{array}$ & & $\begin{array}{c}2.88 \\
(0.95-8.70)\end{array}$ & $\begin{array}{c}1.53 \\
(0.44-5.29)\end{array}$ & & $\begin{array}{c}4.13^{*} \\
(1.62-10.53)\end{array}$ & $\begin{array}{c}2.69 \\
(0.97-7.46)\end{array}$ & \\
\hline Smoking (yes/no) & $\begin{array}{c}1.43 \\
(0.75-2.71)\end{array}$ & $\begin{array}{c}1.22 \\
(0.62-2.42)\end{array}$ & & $\begin{array}{c}1.24 \\
(0.47-3.22)\end{array}$ & $\begin{array}{c}0.97 \\
(0.35-2.74)\end{array}$ & & $\begin{array}{c}1.66 \\
(0.35-7.93)\end{array}$ & $\begin{array}{c}0.98 \\
(0.19-5.13)\end{array}$ & \\
\hline $\begin{array}{l}\text { eGFR }<60 \mathrm{ml} \mathrm{min}^{-1} \\
\text { per } 1.73 \mathrm{~m}^{2}(v s . \geqslant 60)\end{array}$ & $\begin{array}{c}6.20^{*} \\
(3.01-12.78)\end{array}$ & $\begin{array}{c}4.39^{*} \\
(2.05-8.33)\end{array}$ & $\begin{array}{c}2.76^{* *} \\
(1.16-6.60)\end{array}$ & $\begin{array}{c}18.86^{*} \\
(6.07-58.56)\end{array}$ & $\begin{array}{c}14.72^{*} \\
(4.59-47.16)\end{array}$ & $\begin{array}{c}14.79 * \\
(3.63-60.28)\end{array}$ & $\begin{array}{c}3.22 * \\
(1.13-9.16)\end{array}$ & $\begin{array}{c}1.90 \\
(0.61-5.94)\end{array}$ & \\
\hline Hyperuricemiaa (yes/no) & $\begin{array}{c}4.18^{*} \\
(2.10-8.33)\end{array}$ & $\begin{array}{c}3.25^{* *} \\
(1.58-6.71)\end{array}$ & $\begin{array}{c}2.66^{* *} \\
(1.11-6.38)\end{array}$ & $\begin{array}{c}2.99 * * \\
(1.18-7.56)\end{array}$ & $\begin{array}{c}2.75^{* *} \\
(1.03-7.34)\end{array}$ & $\begin{array}{c}1.59 \\
(0.42-6.10)\end{array}$ & $\begin{array}{c}3.13^{* *} \\
(1.25-7.81)\end{array}$ & $\begin{array}{c}2.65^{* *} \\
(1.00-6.99)\end{array}$ & $\begin{array}{c}2.44 \\
(0.88-6.76)\end{array}$ \\
\hline
\end{tabular}

Abbreviations: BMI, body mass index; $\mathrm{Cl}$, confidence interval; eGFR, estimated glomerular filtration rate; OR, odds ratio.

Age, sex and all significant risk factors in the age-adjusted analysis were included in the multivariate model. Odds ratios were calculated for increments of risk for the presence of higher grade of renal arteriolar walll thickening (equal to or higher than the mean value).

${ }^{*} P<0.005,{ }^{*} P<0.05$.

aWe used the hyperuricemia defined as $\geqslant 7 \mathrm{mgdl}^{-1}$ for all and men, and $\geqslant 6 \mathrm{mgdl}^{-1}$ for women as independent variable. These values were selected as the best discriminators in unadjusted model (the data of other definition were not shown).

of renal arteriolar damage remained significant, independent of age, hypertension and diabetes mellitus status.

From the present study, we cannot confirm whether the increased UA levels were the cause of renal arteriolopathy or a consequence of renal arteriolopathy, owing to the cross-sectional design of the study. The increased UA levels in patients with CKD could be attributed to the effect of a low eGFR, resulting in a decreased excretion of urate. Therefore, a low eGFR rather than higher UA levels might be associated with renal arteriolopathy. However, the associations between hyperuricemia and the parameters of renal arteriolopathy, such as hyalinosis and wall thickening, were statistically significant for all patients, even after including an adjustment for eGFR in the multivariate logistic models. Therefore, these findings suggest that increased UA levels might cause renal arteriolopathy. Indeed, accumulating evidence supports this hypothesis. First, UA might have a direct effect on the cells that determine the structure of the vessels. UA has been shown to promote the proliferation of vascular smooth muscle cells and endothelial dysfunction. ${ }^{15,16}$ Moreover, UA could exacerbate cyclosporine nephropathy, which is characterized by severe arteriolopathy and involves blockade of the nitric oxide pathway. ${ }^{17}$ These findings suggest that UA might be involved in the process of arteriolosclerosis. Hyperuricemia might have a significant effect on afferent arterioles, which are essential for the regulation of glomerular hemodynamics and blood pressure, as shown in a previous animal study. 6

Although the clinical relevance of the association between increased UA levels and renal arteriolopathy remains to be determined more precisely, the observed association might be of clinical importance. Hill et al. ${ }^{7,8}$ reported that the presence of renal arteriolar hyalinosis might be a potential marker for the disruption of glomerular hemodynamic autoregulation and favor focal segmental glomerulosclerosis and/or ischemic glomerulosclerosis. As such dysregulation is involved in the progression of many types of kidney disease, ${ }^{18,19}$ increased UA might be a common exacerbating factor for the progression of CKD. The previous study demonstrated that renal arteriolopathy induced by hyperuricemia correlated with glomerular capillary pressure in the animal model of hyperuricemia using micropuncture techniques. ${ }^{9}$ These findings suggested that glomerular hypertension might be involved in the association between hyperuricemia and glomerulosclerosis.

In a therapeutic context, the results of the present study might be important. Some drugs, such as diuretics and some types of angiotensin receptor blockers, could affect serum UA levels. A decrease in serum UA levels was associated with a reduction in renal events in the Reduction of Endpoints in Non-Insulin-Dependent Diabetes Mellitus With the Angiotensin II Antagonist Losartan Trial (RENAL study), in which approximately half of the participants were using diuretics. ${ }^{20}$ Therefore, whether the changes in serum UA in response to these drugs affect renal arteriolopathy and subsequent renal outcome remains to be determined. A clinical study is needed to address this important issue.

In the present study, the association between UA and renal arteriolar hyalinosis was comparable between men and women. However, the cutoff value of UA, above which the risk of arteriolar hyalinosis was increased, might differ between the sexes: $\geqslant 7 \mathrm{mg} \mathrm{dl}^{-1}$ 
for men and $\geqslant 5 \mathrm{mg} \mathrm{dl}^{-1}$ for women. Similarly, a sex difference in the cutoff value of UA was also observed in the association with arteriolar wall thickening: $\geqslant 7 \mathrm{mg} \mathrm{dl}^{-1}$ for men and $\geqslant 6 \mathrm{mg} \mathrm{dl}^{-1}$ for women. Although the cause of the sex difference in the cutoff values was unclear, a difference in the distribution of UA between the sexes might be involved in the mechanism. Interestingly, we have previously reported that hyperuricemia, defined as serum $\mathrm{UA} \geqslant 8.0 \mathrm{mg} \mathrm{dl}^{-1}$ in men and $\geqslant 5 \mathrm{mg} / \mathrm{dl}^{-1}$ in women, significantly increased the risk of developing renal insufficiency in the general population. ${ }^{3}$ This cutoff value of UA for developing renal failure might be partially reflected in the cutoff value of UA for increasing the risk of renal arteriolopathy.

There are several limitations to the present study. First, we cannot rule out the possibility of a sampling bias in the renal biopsy specimens; the grade of the renal microvessel lesion may not have truly reflected the average severity in the whole kidney. However, we demonstrated that the grade of severity was linearly correlated with age and blood pressure in the present study, which is in agreement with the results of a previous autopsy-based study. ${ }^{10}$ Therefore, the effects of such a bias may only be slight. Second, the cohort of patients with CKD in the present study included fewer patients with diabetic nephropathy and hypertensive nephrosclerosis because renal biopsy is generally not indicated for such patients. Therefore, whether the observed association between hyperuricemia and renal arteriolopathy characterized by hyalinosis and wall thickening might be generally applied to CKD of any etiology is not clear. However, a recent study has demonstrated a dose-response relationship between serum UA and early decline in renal function among patients with type 1 diabetes. ${ }^{21}$ This observation and the present results both suggest that the role of UA in the progression of CKD might be independent of the etiology of CKD.

In conclusion, we found that a higher level of serum UA was significantly associated with renal arteriolopathy, independent of age, hypertension and diabetes mellitus, among patients with CKD who underwent renal biopsy. There might be a sex difference in the cutoff value of UA above which the risk of renal arteriolopathy increases. These findings suggest that UA may cause the progression of CKD through its effect on preglomerular arterioles. Large prospective trials are needed to determine the efficacy of the strategies for decreasing serum UA levels to retard the progression of CKD.

\section{ACKNOWLEDGEMENTS}

We thank the following doctors who gave invaluable advice and support: A Miyagi, A Hirano, J Ishikawa, M Miyazato, K Tokashiki, N Tomiyama, S Chinen, M Yamazato and A Ishida. We are also grateful to S Hatoma and M Ohta for technical assistance, and Y Katsumata for advice on the statistical analysis. Finally, we appreciated Dr Y Taguma (Sendai Shakai-hoken Hospital, Sendai, Japan) for fundamental advice.
1 Kang DH, Nakagawa T, Feng L, Watanabe S, Han L, Mazzali M, Truong L, Harris R, Johnson RJ. A role for uric acid in the progression of renal disease. J Am Soc Nephrol 2002; 13: 2888-2897.

2 Iseki K, Ikemiya Y, Inoue T, Iseki C, Kinjo K, Takishita S. Significance of hyperuricemia as a risk factor for developing esrd in a screened cohort. Am J Kidney Dis 2004; 44: 642-650.

3 Iseki K, Oshiro S, Tozawa M, Iseki C, Ikemiya Y, Takishita S. Significance of hyperuricemia on the early detection of renal failure in a cohort of screened subjects. Hypertens Res 2001; 24: 691-697.

4 Bo S, Cavallo-Perin P, Gentile L, Repetti E, Pagano G. Hypouricemia and hyperuricemia in type 2 diabetes: two different phenotypes. Eur J Clin Invest 2001; 31: 318-321.

5 Ohno I, Hosoya T, Gomi H, Ichida K, Okabe H, Hikita M. Serum uric acid and renal prognosis in patients with iga nephropathy. Nephron 2001; 87: 333-339.

6 Mazzali M, Kanellis J, Han L, Feng L, Xia YY, Chen Q, Kang DH, Gordon KL, Watanabe S, Nakagawa T, Lan HY, Johnson RJ. Hyperuricemia induces a primary renal arteriolopathy in rats by a blood pressure-independent mechanism. Am J Physiol Renal Physiol 2002; 282: F991-F997.

7 Hill GS, Heudes D, Bariéty J. Morphometric study of arterioles and glomeruli in the aging kidney suggests focal loss of autoregulation. Kidney Int 2003; 63: 1027-1036.

8 Hill GS, Heudes D, Jacquot C, Gauthier E, Bariéty J. Morphometric evidence for impairment of renal autoregulation in advanced essential hypertension. Kidney Int 2006; 69: 823-831.

9 Sánchez-Lozada LG, Tapia E, Avila-Casado C, Soto V, Franco M, Santamaría J, Nakagawa T, Rodríguez-Iturbe B, Johnson RJ, Herrera-Acosta J. Mild hyperuricemia induces glomerular hypertension in normal rats. Am J Physiol Renal Physiol 2002; 283: F1105-F1110.

10 Kubo M, Kiyohara Y, Kato I, Tanizaki Y, Katafuchi R, Hirakata H, Okuda S, Tsuneyoshi M, Sueishi K, Fujishima M, lida M. Risk factors for renal glomerular and vascular changes in an autopsy-based population survey: The Hisayama study. Kidney Int 2003; 63: 1508-1515.

11 Bader H, Meyer DS. The size of the juxtaglomerular apparatus in diabetic glomerulosclerosis and its correlation with arteriolosclerosis and arterial hypertension: a morphometric light microscopic study on human renal biopsies. Clin Nephrol 1977; 8: 308-311.

12 Lhotta K, Rumpelt HJ, König P, Mayer G, Kronenberg F. Cigarette smoking and vascular pathology in renal biopsies. Kidney Int 2002; 61: 648-654.

13 Matsuo S, Imai E, Horio M, Yasuda Y, Tomita K, Nitta K, Yamagata K, Tomino Y, Yokoyama H, Hishida A, GFR CdtJefe. Revised equations for estimated GFR from serum creatinine in japan. Am J Kidney Dis 2009; 53: 982-992.

14 Wu J, Chen X, Xie Y, Yamanaka N, Shi S, Wu D, Liu S, Cai G. Characteristics and risk factors of intrarenal arterial lesions in patients with iga nephropathy. Nephrol Dial Transplant 2005; 20: 719-727.

15 Kang DH, Park SK, Lee IK, Johnson RJ. Uric acid-induced c-reactive protein expression: implication on cell proliferation and nitric oxide production of human vascular cells. J Am Soc Nephrol 2005; 16: 3553-3562.

16 Khosla UM, Zharikov S, Finch JL, Nakagawa T, Roncal C, Mu W, Krotova K, Block ER, Prabhakar S, Johnson RJ. Hyperuricemia induces endothelial dysfunction. Kidney Int 2005; 67: 1739-1742.

17 Mazzali M, Kim YG, Suga S, Gordon KL, Kang DH, Jefferson JA, Hughes J, Kivlighn $\mathrm{SD}$, Lan HY, Johnson RJ. Hyperuricemia exacerbates chronic cyclosporine nephropathy. Transplantation 2001; 71: 900-905.

18 Christensen PK, Hommel EE, Clausen P, Feldt-Rasmussen B, Parving HH. Impaired autoregulation of the glomerular filtration rate in patients with nondiabetic nephropathies. Kidney Int 1999; 56: 1517-1523.

19 Christensen PK, Hansen HP, Parving HH. Impaired autoregulation of GFR in hypertensive non-insulin dependent diabetic patients. Kidney Int 1997; 52: 1369-1374.

20 Miao Y, Ottenbros SA, Laverman GD, Brenner BM, Cooper ME, Parving HH, Grobbee DE, Shahinfar S, de Zeeuw D. Lambers Heerspink HJ. Effect of a reduction in uric acid on renal outcomes during losartan treatment: a post hoc analysis of the reduction of endpoints in non-insulin-dependent diabetes mellitus with the angiotensin II antagonist losartan trial. Hypertension 2011; 58: 2-7.

21 Ficociello LH, Rosolowsky ET, Niewczas MA, Maselli NJ, Weinberg JM, Aschengrau A Eckfeldt JH, Stanton RC, Galecki AT, Doria A, Warram JH, Krolewski AS. High-normal serum uric acid increases risk of early progressive renal function loss in type 1 diabetes: results of a 6-year follow-up. Diabetes Care 2010; 33: 1337-1343. 